\title{
Evaluation of The Anxiety Levels of Orthodontics Patients During Covid-19 Pandemic
}

Hatice Kök(0000-0002-5874-9474) ${ }^{\alpha}$, Zehra İleri(0000-0001-5718-8022) ${ }^{\alpha}$, Hasan Hüseyin Tekin(0000-0002-6300-4098) ${ }^{\beta}$

Selcuk Dent J, 2021; 8: 120-126 (Doi: 10.15311/selcukdent. 909895)

Basvuru Tarihi: 05 Nisan 2021 Yavına Kabul Tarihi: 14 Nisan 2021

\section{ABSTRACT}

Evaluation of The Anxiety Levels of Orthodontics Patients During Covid-19 Pandemic

Background: We aimed to evaluate the anxiety of patients receiving orthodontic treatment during the COVID-19 pandemic.

Methods: A 27-questions online questionnaire form was designed to assess orthodontic patients' anxiety levels regarding the COVID-19 pandemic with Google Forms (Google LLC, Mountain View,CA,ABD). The questionnaire link sent to the 400 patients and the study conducted with 262 volunteer patients(VP) who were receiving active orthodontic treatment the during pandemic and who agreed to fill out our questionnaire voluntarily. Descriptive statistics with percentages, chi-square and independent $t$ test were used for statistical analysis.

Results: The 53.8\%VP were women who were more anxious than men about the pandemic and its effect on their orthodontic treatments. $49.6 \% \mathrm{VP}$ were anxious, $44.7 \% \mathrm{VP}$ were calm. $40.5 \%$ of the participants stated that they did not have any problems with their orthodontic treatments during the pandemic.80.2\%VP communicated with their orthodontist during the COVID-19 pandemic.97.3\%VP said that they trust their orthodontist in the management and guidance of their treatment during the COVID19 pandemic.51.9\%VP declared that they did not anxious when attending their orthodontic appointments. The most common complaint $(21.4 \%)$ of the patients during this period was bracket breaking and wire sinking. The major concern about pandemic affect on their treatment was delay of the treatment (59.4\%).

Conclusion: It's important to inform patients about their treatments and the pandemic process. Establishing a strong patient-clinician relationship is beneficial. The VP did not have any severe anxiety about the pandemic and its adverse affects on their orthodontic treatment.

\section{KEYWORDS}

Covid-19, Pandemic, Orthodontics, Anxiety

Pandemics such as cholera, smallpox, Spanish flu, HIV/AIDS, Ebola have affected many civilizations throughout human history. ${ }^{1}$ Today, pathogens can spread rapidly and become a worldwide epidemic due to globalization, as in the coronavirus (COVID-19) pandemic. The COVID-19 was identified in Wuhan city of China on December 31, 2019. The World Health Organization (WHO) declared on January 7, 2020 that it was a new type of coronavirus that had not been

\section{ÖZ}

Covid-19 Pandemi Sürecinde Ortodonti Hastalarının Anksiyete Düzeylerinin Değerlendirilmesi

Amaç: Çalışmamızda; COVID-19 pandemisi sırasında ortodontik tedavi gören hastaların anksiyetesinin değerlendirilmesi amaçlanmıştır.

Gereç ve Yöntemler: Ortodontik hastaların COVID-19 salgınına ilişkin kaygı düzeylerini değerlendirmek için Google Forms (Google LLC, Mountain View, CA, ABD) ile 27 soruluk çevrimiçi bir anket formu tasarlanmıştır. Anket bağlantısı 400 hastaya gönderilmiş, ve çalışmamız COVID-19 Pandemisi sırasında aktif ortodontik tedavi gören ve anketimizi gönüllü olarak doldurmayı kabul eden 262 gönüllü hasta (VP) ile gerçekleştirilmiştir. İstatistiksel analiz için yüzdelik tanımlayıcı istatistikler, ki-kare ve bağımsız $t$ testi kullanılmıştır.

Bulgular: Çalışmamızda, \% 53,8 kadın VP, pandemi ve ortodontik tedavilere etkisi konusunda erkeklerden daha endişeli oldukların bildirmişlerdir. \% 49.6 VP endişeli, \% 44.7 VP ise sakin olduklarını bildirmişlerdir. Katılımcıların \% 40,5'i pandemi sırasında ortodontik tedavilerinde herhangi bir sorun yașamadıklarını belirtmiștir. \% 80,2 VP, COVID-19 salgını sırasında ortodontistleri ile iletişim kurmuştur. \% 97,3 VP, COVID-19 salgını sırasında tedavilerinin yönetimi ve rehberliği konusunda ortodontistlerine güvendiklerini bildirmişlerdir \% 51.9 VP ortodonti randevularına gelirken endişelenmediğini belirtmiştir. Bu dönemde hastaların en sık şikayeti $(\% 21,4)$ braket kırılması ve tel batmasıdır. VP lerin, pandeminin tedavileri üzerindek etkisi ile ilgili en büyük endişeleri, tedavinin gecikmesidir (\% 59,4).

Sonuç: Hastaları tedavileri ve pandemi süreci hakkında bilgilendirmek önemlidir. Güçlü bir hasta-klinisyen ilişkisi kurmak faydalıdır. VP'nin pandemi ve pandeminin ortodontik tedavi üzerindeki olumsuz etkileri konusunda ciddi bir endişeye sahip olmadıkları gözlenmişsir.

\section{ANAHTAR KELIMELER}

Covid-19, Pandemi, Ortodonti, Anksiyete

detected in humans before. When the first COVID-19 case that was European origin determined in our country on March 11, the disease began to appear in 48 European countries and deaths in some, too. On the same date, the WHO declared pandemic because of its widespread transmission potential. ${ }^{2,3}$ Then, our government has implemented a series of emergency plans gradually to control the disease in our country. Such as the closing of schools, curfews for people over

\footnotetext{
${ }^{\alpha}$ Faculty of Dentistry, Department of Orthodontics, Selçuk University, Konya

${ }^{\beta}$ Faculty of Health Sciences, Department of Social Work, Necmettin Erbakan University, Konya
} 
65 and under 20 years of age, general curfews on weekends, cessation of travel between countries and cities, the transition to the teleworking or flexible working, quarantine imposed on sick people and their contacts, only emergency dental care implementation, etc. With the reduction of cases, as of June 1, the normalization process was started in our country. ${ }^{4,5}$

Quarantine that may affect people's psychology, emotion, and economy severely is the isolation of the person who is potentially infected with an infectious agent (and therefore at risk of disease) from the public for the more significant public benefit. ${ }^{6}$ Attention should be paid that both the risky person's isolation and taking convenient infection control preventions in isolation locations for effectiveness. ${ }^{6}$ Huang and $\mathrm{Zhao}^{7}$ stated the COVID-19 pandemic causes a significant psychological loading on the Chinese community. They reported that the peoples who were healthcare workers, youngers, and lose sleep about the epidemic were at a high risk of displaying psychological problems. ${ }^{7}$ Psychologically, there is no unity of opinion on the issue that the elderly or the young are more affected. The young people are prone to get a significant sum of information from social media that can cause stress. ${ }^{8}$ On the other hand, the most elevated mortality ratios appeared in the elderly during the pandemic. The immunosuppressed patients and infected patients' family members and residents of high incidence areas could struggle with mental health problems. ${ }^{9}$ The relationship between the presence of chronic disease and higher rates of distress has been reported. ${ }^{10}$ Additionally, anxiety-related behaviors could be seen in the population because of the uncertainty, insufficient information, the lack of medical mask, alcohol or medication, healthcare professionals' working in close contact with the patient and the virus with inadequate medical equipment, also working for long periods without rest. ${ }^{7}$ Huang et al. ${ }^{11}$ and Kang et al. ${ }^{12}$ stated that the nurses and doctors were displaying high anxiety, stress, and mental disorders (like as posttraumatic stress) symptoms in particular.

Dentists are at risk of contracting COVID-19 due to faceto-face relation with patients, exposure to saliva, blood, and other body fluids, using sharp tools, and aerosols generated during routine dental treatments. Indeed, dentists are more likely to be affected by the new coronavirus disease than doctors and nurses. The COVID-19 could be transmitted mainly by direct contact and droplet. COVID-19 is also expected to spread when exposed to high concentrations of aerosols in a relatively closed environment and pose potential risks for dentists, auxiliary staff, and patients. ${ }^{13}$ They could also be carriers of the disease. Orthodontic treatment in which the patient's cooperation is crucial is a long-term treatment that progresses with monthly appointments. The COVID-19 quarantine process also caused delays in orthodontic treatments. Despite the return to normalization from quarantine, the pandemic has not yet been brought under control. However, little is known about orthodontic patients' COVID-19 knowledge and anxiety levels. Determining these factors will be useful in creating map out a route for clinicians.

The questionnaire; is a research material consisting of a series of questions aimed at obtaining information from individuals or about individuals in order to define, compare or explain the knowledge, attitudes, and behavior of individuals. Visual Analogue Scale (VAS); is a test that has been used for a long time and has been accepted in the world literature. In subjective situations perceived by emotions, it enables the values that cannot be measured numerically to be converted into numerical ones. A segment (VAS Bar) drawn between two constrained points represents a specific range of numbers, such as $0-10$ or $0-100$. VAS is easily and quickly understood by the participants. The participant is asked to place a dot, line, or mark on the VAS bar on the area that corresponds to his emotions and thoughts. In light of this knowledge; the purpose of our study is the evaluation of the anxiety levels of orthodontics patients during the COVID-19 pandemic. The $\mathrm{H}_{0}$ hypothesis; there is no relationship between the anxiety levels of orthodontics patients and the COVID19 pandemic.

\section{MATERIALS AND METHODS}

This study was conducted on patients who were receiving active orthodontic treatment in Selcuk University Faculty and accepted to fill in our study questionnaire voluntarily. Each patient and their parents informed by online written form and signed the consent form. The VP could withdraw from the study without any justification at any time. Ethics committee approval was obtained for the study from Selcuk University Faculty of Dentistry.

The number of our clinic active patients whose telephone numbers were accessible were four hundred. The inclusion criteria were 12-20 years old, willing to participate in the questionnaire, ongoing orthodontic treatment. The exclusion criteria were cleft lip or palate, learning difficulties, mental retardation, orthodontic treatment finished before the COVID-19 pandemic.

The printed 20 of questionnaires answered face to face by the VP who came to their orthodontic appointment just because to check our questionnaire and questions. The online, non-commercial questionnaire was preferred to prevent the spread of COVID-19 by 
droplets or contact. A 27-questions online questionnaire form was designed to assess orthodontic patients' anxiety levels regarding the COVID-19 pandemic with Google Forms (Google LLC, Mountain View, CA, ABD). The $21^{\text {st }}$ and $25^{\text {th }}$ questions included the Visual Analogue Scale (VAS) that consisted of a ruler between 0-10 values. Each of the volunteer participants evaluated and marked "the level of anxiety about the COVID-19 Pandemic" and "levels of anxiety about the COVID-19 Pandemic's effect on treatment on their treatment" on the VAS. It was not included the questions that describe the patient's identification. The questionnaire link sent to the 400 patients and each patient filled out only one questionnaire. The seventy-two hours were given to answer the questionnaire for patients.

\section{Statistical Analysis}

The questionnaire data obtained from VP were analyzed using SPSS 20.0 (IB Inc., Chicago, IL, USA) program within a 95\% confidence interval, and $\mathrm{p}<0.05$ was considered statistically significant. Descriptive statistics were used to determine age, gender, COVID-19 knowledge, and awareness. The behaviors, emotions, wishes to go to the hospital, and concerns about treatment of females and males during the COVID-19 pandemic process were compared and evaluated with chi-square analysis. Also, the level of anxiety about the coronavirus pandemic and impact on VAS was performed with independent $t$ test.

\section{RESULTS}

Two hundred sixty-two patients of a total of four hundred patients answered the questionnaire by clicking the link, which means that the questionnaires' response rate was $65.5 \%$. The $93.9 \%$ ( $n: 246)$ VP did not have chronic illnesses that require constant medical supervision. The age and gender results were given in Figure 1. The VP' mean age was 16.92 years. The 93.9\% (n:231) had no systemic diseases, $11.8 \%$ (n:31) lived with their grandparents, $13.7 \%(\mathrm{n}: 36)$ needed socio-economic support. The $90.5 \%$ (n:237) VP declared that they were knowledgeable enough about COVID-19. The $97.3 \%$ (n:255) did not infected by COVID-19 and $91.2 \%$ (n:239) did not contact with COVID-19 positive patient. Also, the results of the VP' behaviors, safeguards, and emotions due to COVID-19 were given in Figure 1.

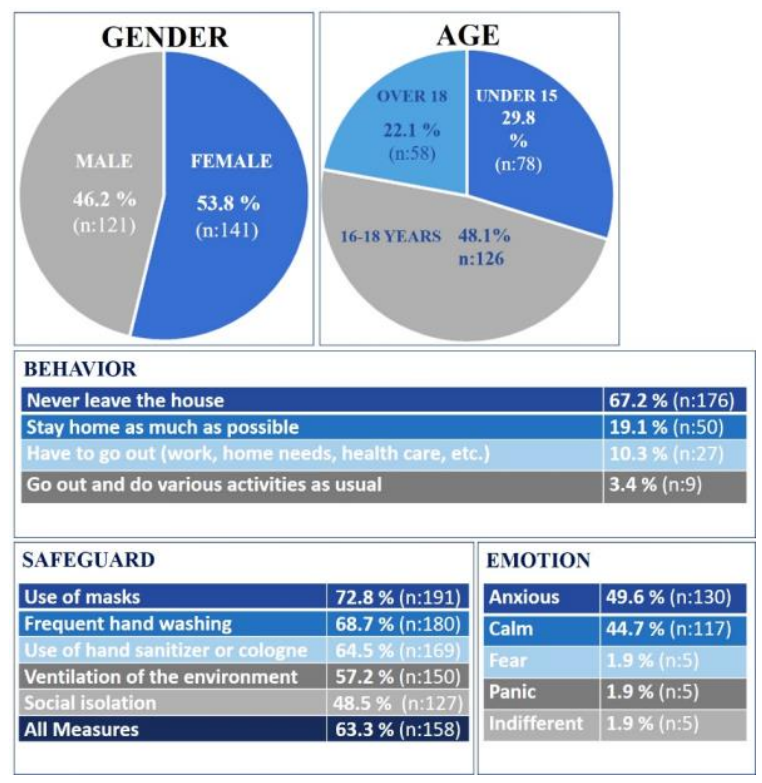

Figure 1

The results of the age, gender, and the VP' behaviors,safeguards,emotions due to COVID-19
The $80.2 \%$ ( $\mathrm{n}: 210)$ VP communicated with their orthodontist during the COVID-19 pandemic. The 97.3\% $(n: 255)$ VP said that they trust their orthodontist in the management and guidance of their treatment during the COVID-19 pandemic process. The $40.5 \%$ (n:106) VP had no problems, the most common problems were bracket breakage and wire sinking $21.4 \%$ (n:56). The results of the concerning VP' orthodontics, the level of anxiety about pandemic (VAS), and the level of anxiety about pandemic's effect on treatment (VAS) were given in Figure 2. The $\mathrm{H}_{0}$ hypothesis was accepted. The $32.4 \%$ VP contacted with their orthodontist because of the orthodontic problem. $97.3 \%$ ( $n: 255)$ VP declared their trust to their orthodontist. The $51.9 \%$ (n:136) VP declared that they did not anxious when attending their orthodontic appointments. Attending orthodontic appointments caused anxiety about infecting themself and their family with COVID-19 at the $34 \%$ (n:89) VP. The 10.7\% (n:28) VP was concerned about dental clinics to carry a high risk and the $3.4 \%$ (n:9) VP believed that their treatment was not urgent.

The 1.5\% (n:4) VP said that they did not find adequate the institution's COVID-19 measures. The important measures in dental practices in the current pandemic conditions according to VP were the fever measurement at the entrance of the institution $89.3 \%$ (n:234), physician's use of a disposable surgical mask (N95, FFP2, FFP3) 77.5\% (n:203), the physician's use of a visor in addition to the surgical mask $75.6 \%$ (n:198), avoiding meeting other patients in the waiting room $74.8 \%$ (n:196), alcoholbased disinfectant for patient use in the waiting room $74.4 \%$ ( $\mathrm{n}: 195)$, physician's use of disposable gowns $74 \%$ (n:194), use of protective equipment (mask, gloves) for patients 72.95 (n:191).

The results of the comparison between males and females were given in Table 1. 


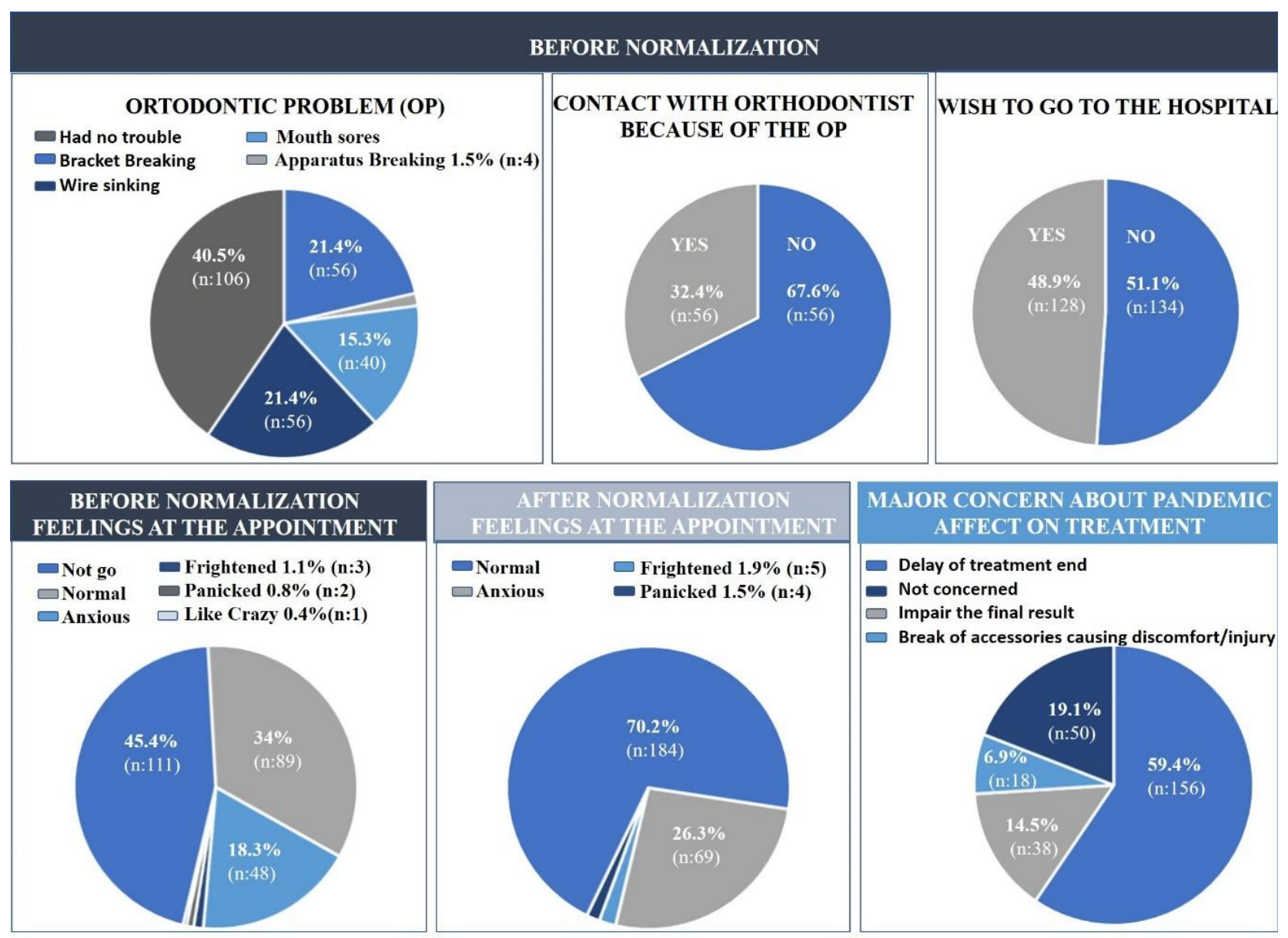

\section{LEVEL OF ANXIETY ABOUT THE COVID-19 (VAS)}

262 responses

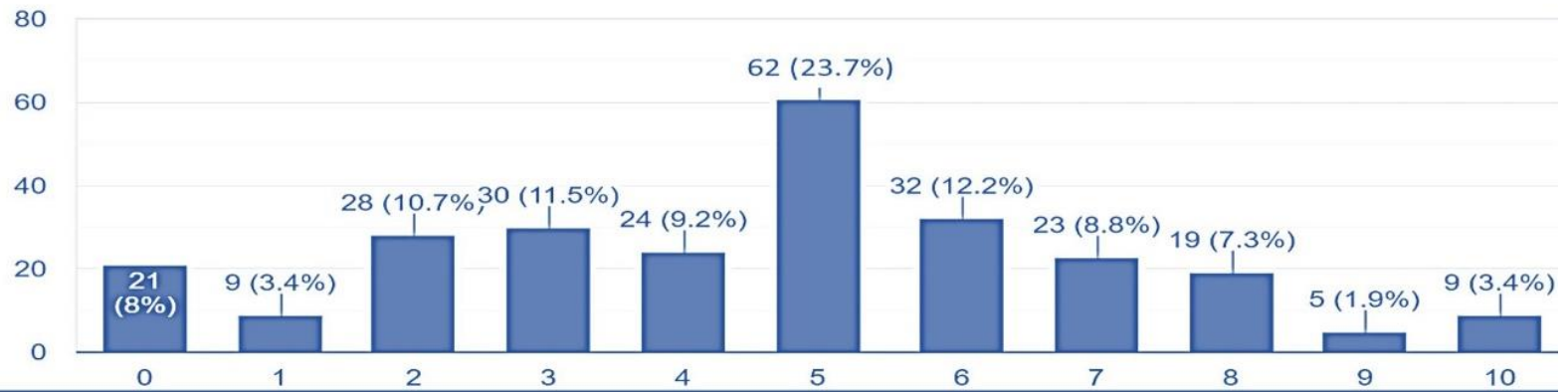

LEVEL OF ANXIETY ABOUT THE COVID-19 PANDEMIC'S EFFECT ON TREATMENT (VAS)

262 responses

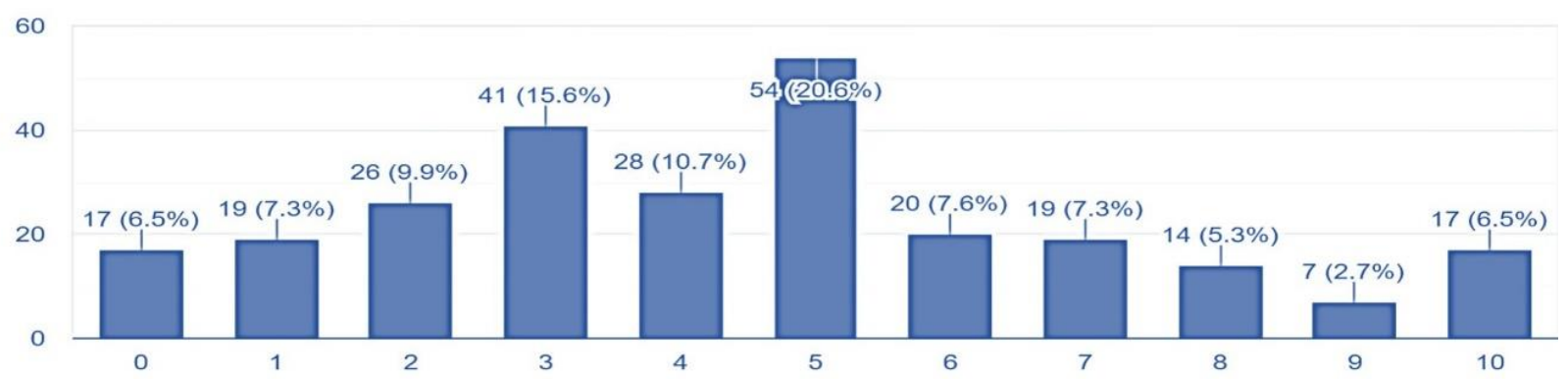

Figure 2

The results of the concerning VP' orthodontics, the level of anxiety about pandemic (VAS), and the level of anxiety about pandemic's effect on treatment (VAS) 
Table 1.

The results of the comparison between males and females ${ }^{\mathrm{a}} \mathrm{Chi}-$ square test. ${ }^{\top}$ Independent $t$ test. * Statistically significant for $p<.05$

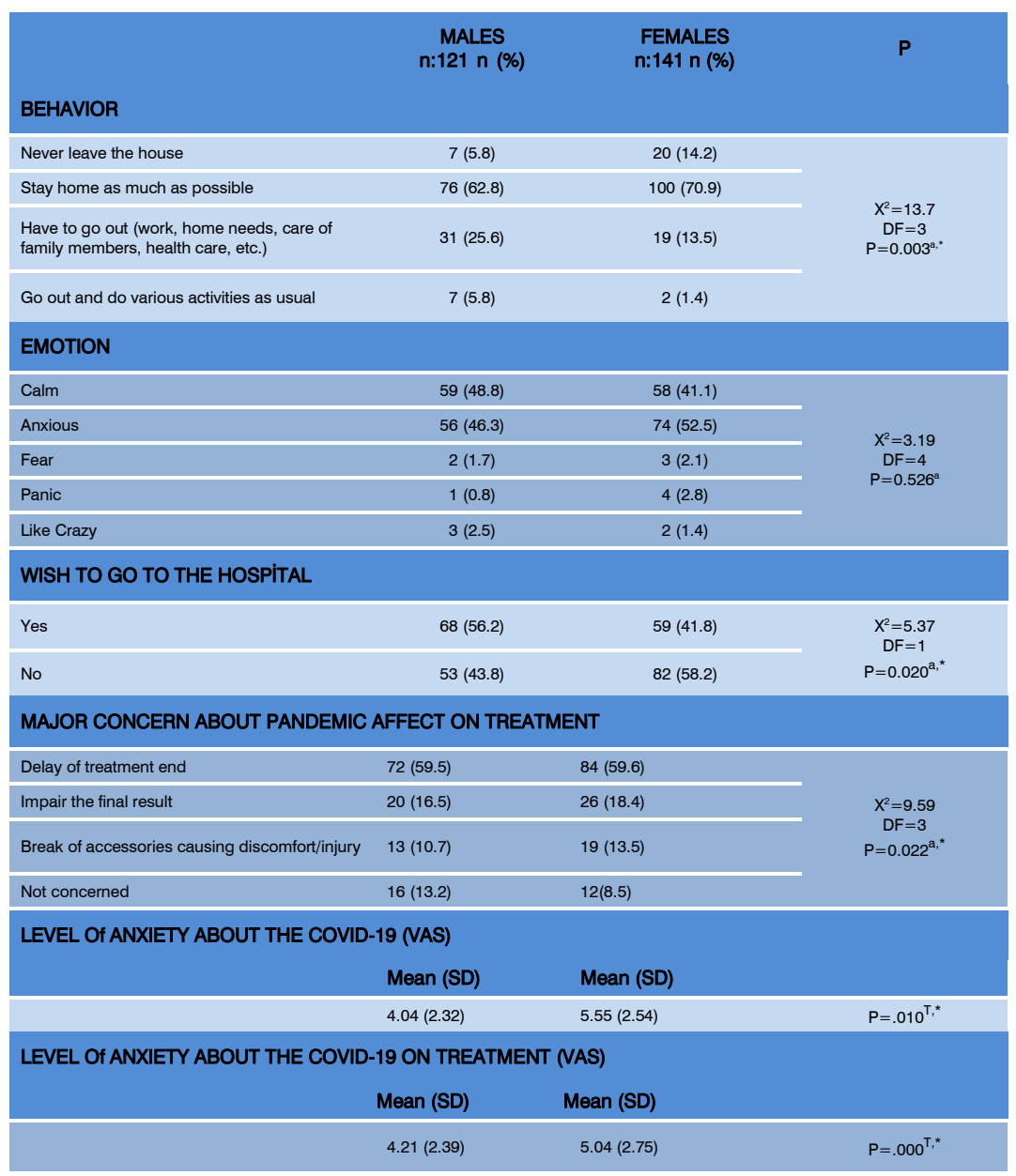

\section{DISCUSSION}

In our study, we wanted to evaluate the situation from the patient's point of view and have an idea about determining the ways and methods to be followed by the clinician in sudden emerging situations such as a pandemic. According to our results, the VP trust their orthodontist in the management and guidance of their treatment during the COVID-19 pandemic process, so the VP did not show high anxiety.

Qiu et al. ${ }^{14}$ stated that the female showed significantly higher psychological distress than male in COVID-19 pandemic. It is in accordance with our results and previous research which concluded that females were much more vulnerable to stress and more likely to develop post-traumatic stress disorder. ${ }^{14,15}$ People under 18 years had the lowest COVID-19 Peritraumatic Distress Index (CPDI) scores. ${ }^{15}$ Huang and Zhao ${ }^{7}$ reported that there was no statistically significant difference in the prevalence of generalized anxiety disorder (GAD), depressive symptoms (DS), and sleep quality by gender in COVID-19 pandemic. The prevalence of GAD and DS was significantly higher in participants younger than 35 years. ${ }^{7}$ Our study was conducted on relatively young individuals, and $77.9 \%$ of VPs were 18 years old or younger. The $49.6 \%$ of the participants stated that they were anxious, and $44.7 \%$ VP indicated they were calm.
Those who reported fear and panic feelings were quite low (1.9\%). We did not suddenly face the pandemic; unfortunately, there were countries affected by the pandemic and its effects before our country, and we had known at least little about COVID-19. We think that early taken measures, informing the society about epidemics and precautions rapidly- effectively with all communication tools and ensuring rapid adaptation in the clinical process and patient admission were effective to preventing panic and fear. Another pleasant effect of these was the increase in the patients' rate of compliance with the measures taken during the pandemic process. Only $3.4 \%$ VP declared they went out as normal during the quarantine. Cotrin et al. ${ }^{16}$ reported that regarding the feeling about the COVID-19 pandemic and social distancing, $44.7 \%$ of the patients were calm, $23.4 \%$ reported to be afraid (fear), $22.9 \%$ were anxious, $5.6 \%$ were indifferent, and $3.4 \%$ were in a panic. The mean level of anxiety related to the COVID-19 pandemic was $4.98 \pm 2.42$. In accordance with our study, the females' level of anxiety about COVID-19 was $5.55 \pm 2.54$, and it was $4.04 \pm 2.32$ for males.

Most of the VP had no chronic illness, had not infected by COVID-19, and had not contacted COVID-19 positive patients. The $11.8 \%$ (n:31) lived with their grandparents. Following the government's decision to only handle emergency dental cases, protective equipment was provided for clinicians, and emphasis was placed on use during every patient intervention. According to VP, the fever measurement at the entrance of the institution is most important measure (89.3\%). Only $1.5 \%$ VP found the institution's COVID-19 measures inadequate but the $34 \%$ (n:89) VP said they were anxious about infecting themself and their family with COVID-19 at the orthodontic appointment attending. The $10.7 \%$ (n:28) VP was concerned about dental clinics to carry a high risk and the $3.4 \%$ $(n: 9)$ VP believed that their treatment was not urgent. The $51.9 \%$ (n:136) VP declared that they did not worry when attending their orthodontic 
appointments. We thought that when they saw their doctors in protective clothing in a way they had not seen before, it might cause anxiety and fear during the appointment in young people, but on the contrary, we found that this caused the patients to lessen their anxiety. Seeing that all measures were taken and implemented or the transition to a normalization period may have caused such a result.

Before normalization, $40.5 \%$ of VP had had no problems, the most common problems were bracket breakage and wire sinking (21.4\%). The $32.4 \%$ VP contacted with their orthodontist because of the orthodontic problem. The $97.3 \%$ ( $n: 255)$ VP declared their trust to their orthodontist. During the pandemic, the $80.2 \%$ VP stated that their doctors were in contact with them. It may be the result of informing the patients in detail at the beginning of the treatment and good communication with their doctors. The most important method to improve patient's compliance is verbally praising the patient and communicating with the patient and the parents. ${ }^{17,18}$ Verbal communication could not be carried out much due to the pandemic. However, we think that phone calls, texting, or video calls have a positive effect on the VP' emotional condition.

Peloso et al. ${ }^{19}$ stated that the orthodontic patients were more anxious about a delay in their treatment finishing $48.7 \%$ than patients those receiving other specialties of dental treatment, $42.9 \%$ of patients were not anxious about the impact of quarantine on their dental treatment. ${ }^{19}$ The impact of quarantine on their orthodontic treatment was delay in the end of treatment $48.3 \%$ followed by breakage of brackets worsening the malocclusion $13.3 \%, 34.7 \%$ patients had no concern with the impact of the quarantine in their orthodontic treatment. ${ }^{16}$ In our study $59.4 \%$ VP major concern about COVID-19 pandemic affect was delays the end of treatment. This is an inevitable side effect of the pandemic, Beckwith et al. $^{20}$ and Jung ${ }^{21}$ stated that appointment missing and brackets breaking increased treatment time significantly. On the other hand, $19.1 \%$ VP had no concern. With normalization, it was observed that the VP' anxiety level at orthodontic appointments decreased and their emotional states normalized, mostly.

The findings of this study must be seen considering some limitations. The limitations of this study are time constraints, small sample size, the crosssectional design, and the reliance on self-reported questionnaires.

\section{CONCLUSION}

- Within the limitation of this study, the following conclusions can be drawn:

- It is important to inform patients about their treatments and the pandemic process.

- Establishing a strong patient-clinician relationship is beneficial.

- Seeing that the necessary precautions were taken prevented fear and panic.

- Our VP did not have any severe anxiety about the pandemic and its adverse effects on their orthodontic treatment.

- The female VP were more anxious than male VP about the effect of the pandemic on their orthodontic treatments.

- The $40.5 \%$ of VP did not have any problems with their orthodontic treatments during the COVID-19 pandemic.

- The most common problems were bracket breaking and wire sinking.

- The most common anxiety about orthodontic treatment was that the COVID-19 pandemic will delay the end of treatment. 


\section{REFERENCES}

1. https://www.businessinsider.com/pandemics-thatchanged-the-course-of-human-history-coronavirus-fluaids-plague\#coronavirus-or-covid-19-2019-present11(AccessDate:8/26/2020).

2. https://www.who.int/emergencies/diseases/novelcoronavirus-

2019?gclid=EAlalQobChMI04e9s83A6wIVGu3tCh3YG wzmEAAYAyAAEgK3XPD BwE

(AccessDate:8/26/2020).

3. https://covid19bilgi.saglik.gov.tr/depo/rehberler/covid19-rehberi/COVID19_REHBERI_GENEL_BILGILER_EPIDEMIYOLOJI_VE_ TAN̄I.pdf (AccessDate:8/26/2020).

4. http://www.konya.gov.tr/konya-il-umumi-hifzissihhakurul-karari (AccessDate:8/26/2020).

5. http://www.kto.org.tr/konya-il-umumi-hifzissihha-kurulkararlari-3147h.htm(AccessDate:8/26/2020).

6. Hawryluck L, Gold WL, Robinson S, Pogorski S, Galea S, Styra R. SARS control and psychological effects of quarantine, Toronto, Canada. Emerging infectious diseases. 2004;10(7): 1206.

7. Huang $Y$, Zhao N. Generalized anxiety disorder, depressive symptoms and sleep quality during COVID19 outbreak in China: a web-based cross-sectional survey. Psychiatry research, 2020;112954.

8. Cheng, C., Jun, H., \& Liang, B. (2014). Psychological health diathesis assessment system: a nationwide survey of resilient trait scale for Chinese adults. Stud Psychol Behav, 12, 735-42.

9. Xiang YT, Yang Y, Li W, Zhang L, Zhang Q, Cheung T, et al. Timely mental health care for the 2019 novel coronavirus outbreak is urgently needed. Lancet Psychiatry. 2020; 7:228-9.

10.Wang, C.; Pan, R.; Wan, X.; Tan, Y.; Xu, L.; Ho, C.S.; Ho, R.C. Immediate psychological responses and associated factors during the initial stage of the 2019 coronavirus disease (COVID-19) epidemic among the general population in China. Int. J. Environ. Res. Public Health 2020; 17, 1729.

11. Huang JZ, Han MF, Luo TD, Ren AK, Zhou XP. [Mental health survey of 230 medical staff in a tertiary infectious disease hospital for COVID-19]. Zhonghua Lao Dong Wei Sheng Zhi Ye Bing Za Zhi. 2020; 38: E001.

12. Kang L, Li Y, Hu S, Chen M, Yang C, Yang BX, et al. The mental health of medical workers in Wuhan, China dealing with the 2019 novel coronavirus. Lancet Psychiatry.2020; 7:e14.

13.Ge ZY, Yang LM, Xia JJ, Fu XH, Zhang YZ. Possible aerosol transmission of COVID-19 and special precautions in dentistry. Journal of Zhejiang UniversitySCIENCE B. 2020;1-8.
14. Quu J, Shen B, Zhao M, Wang Z, Xie B, Xu Y. A nationwide survey of psychological distress among Chinese people in the COVID-19 epidemic: implications and policy recommendations. General psychiatry. 2020; 33(2)

15. Sareen J, Erickson J, Medved MI, et al. Risk factors for post-injury mental health problems. Depress Anxiety 2013; 30:321-7.

16. Mehra T, Nanda RS, Sinha PK. Orthodontists' assessment and management of patient compliance. The Angle Orthodontist.1998;68(2): 115-122.

17.Daniels AS, Seacat JD, Inglehart MR. Orthodontic treatment motivation and cooperation: a cross-sectional analysis of adolescent patients' and parents' responses. American Journal of Orthodontics and Dentofacial Orthopedics. 2009;136(6): 780-787.

18. Peloso RM, Pini NIP, Sundfeld Neto D, Mori AA, Oliveira RCGD, Valarelli FP, Freitas KMS. How does the quarantine resulting from COVID-19 impact dental appointments and patient anxiety levels? Brazilian oral research. 2020; 34

19. Cotrin PP, Peloso RM, Oliveira RC, Oliveira RCG, Pini NIP, Valarelli FP, Freitas KMS. Impact of coronavirus pandemic in appointments and anxiety/concerns of patients regarding orthodontic treatment. Orthodontics \& Craniofacial Research. 2020.

20.Beckwith FR, Ackerman RJ Jr, Cobb CM, Tira $D E$. An evaluation of factors affecting duration of orthodontic treatment. Am J Orthod Dentofacial Orthop.1999 Apr;115(4):439-47.

21.Jung $\mathrm{MH}$. Factors influencing treatment efficiency. Angle Orthod. 2020 Nov 2.

Corresponding Author:

Hatice KÖK

Selçuk University

Faculty of Dentistry,

Department of Orthodontics, Konya, Turkey

Phone : +90 3322231174

Fax : +903322410062

E-mail :dt_kok@hotmail.com 